Шумов В. В.

\title{
КОМПЛЕКСНЫЙ ПОДХОД К РАЗРАБОТКЕ КОНЦЕПЦИИ АВТОМАТИЗАЦИИ ПОГРАНИЧНОЙ ДЕЯТЕЛЬНОСТИ
}

\begin{abstract}
Аннотация: В настоящей работе конкретизированы принципы моделирования пограничной деятельности, рассмотрена последовательность разработки методов и моделей пограничной безопасности, их классификачия. Основной подход (совокупность приемов и способов) к разработке концепции автоматизации заключается в последовательной декомпозиции предметной области на основе классификации мер. Элементы предметной области объединяются в единую систему посредством выявления сквозных процессов, применения циклов пограничной деятельности и управления. Предложенные классификации методов управления режимными, профилактическими и пограничными мерами позволяют получить полный и непротиворечивый перечень пограничных задач, подлежащих автоматизации. Также рассмотрена методология автоматизации пограничной деятельности, основанная на декомпозиции процессов пограничной безопасности. Построение концепции автоматизации пограничной деятельности предполагает использование методов системного анализа и системотехники, методологии ЕТОМ, основных положений теории права, криминологии, теории безопасности, погранологии и погранометрики. В целях создания высокоэффективных систем поддержки принятия решений в сфере обеспечения пограничной безопасности выполнена классификация методов управления пограничной безопасностью. Рассмотрена и обоснована структура режимных, профилактических, охранно-контрольных и оперативно-силовых мер. Разработана структурная схема прочессов первого уровня, включающая два блока: прочессы управления пограничной безопасностью и процессы управления пограничными подразделениями. Ключевые слова: пограничная деятельность, пограничная безопасность, концепчия, автоматизация, методология автоматизации, методы управления, пограничные меры, информационные модели, математические модели, принципы моделирования
\end{abstract}

\section{1. Введение}

Концепция (от лат. conceptio - понимание, система) есть «определённый способ понимания, трактовки какого-либо предмета, явления, процесса, основная точка зрения на предмет и др., руководящая идея для их систематического освещения»1. Под автома-

1 Большая советская энциклопедия: В 30 т. М.: Советская энциклопедия, 1969-1978. 
тизацией понимается «одно из направлений научно-технического прогресса, использующее саморегулирующие технические средства и математические методы с целью освобождения человека от участия в процессах получения, преобразования, передачи и использования энергии, материалов, изделий или информации, либо существенного уменьшения степени этого участия или трудоёмкости выполняемых операций»².

С точки зрения погранологии, методологии управления ${ }^{3}$ и теории организационных систем ${ }^{4}$ пограничную деятельность можно декомпозировать на:

- деятельность по обеспечению пограничной безопасности;

- деятельность по управлению пограничными органами (организациями).

Второе направление является предметом теории организационных систем, с точки зрения которой организационная деятельность подразделяется на (основанием классификации является предмет управления - изменяемый в процессе и результате управления компонент системы) 5 :

- $\quad$ управление составом;

- $\quad$ управление структурой;

- институциональное управление (управление ограничениями и нормами деятельности);

- $\quad$ мотивационное управление (управление предпочтениями и интересами);

- информационное управление (управление информацией, которой обладают участники организационной системы на момент принятия решений);

- управление порядком функционирования (управление последовательностью получения информации и выбора стратегий участниками системы).

Данное направление достаточно полно исследовано и существует множество автоматизированных систем, предназначенных для автоматизации организационно-управленческих задач (1C, SAP и др.).

\section{2. Методы и модели пограничной безопасности}

\section{1. Принципы моделирования пограничной безопасности}

Перечислим некоторые принципы, которым должна соответствовать деятельность по формированию методов и моделей пограничной безопасности, в интересах построения автоматизированных (информационных) систем.

Принцип системности. Процессы обеспечения пограничной безопасности должны быть декомпозированы на отдельные задачи (подсистемы, элементы). Нижний уровень декомпозиции должен обеспечивать формирование тактических (тактико-технических) требований к разрабатываемым автоматизированным системам. Каждая подсистема

2 Википедия. ru.wikipedia.org.

3 Новиков Д.А. Методология управления. М.: Книжный дом «ЛИБРОКОМ», 2012. 128 с. Шумов В.В. Введение в методологию погранологии и погранометрики / Под ред. и с предисл. В.А. Дмитриева. М.: Книжный дом «ЛИБРОКОМ», 2013. 200 с.

4 Новиков Д.А. Теория управления организационными системами. М.: МПСИ, 2005. 584 с. 5 Там же. С. 9-10. 
(элемент) должна рассматриваться не сама по себе, а во взаимодействии с другими подсистемами: по горизонтали - на основе циклов служебной и управленческой деятельности, по вертикали - в соответствии с принципом иерархии. Решение подзадач должно происходить при условии обеспечения интегративных качеств функционирования всей системы.

Принцип иерархии. Методы и модели имеют, как правило, иерархическую структуру. Они должны соответствовать функциональной структуре решаемых государством, обществом, ведомством задач по обеспечению пограничной безопасности.

Принцип унификации. Задачи моделирования, управляемые и управляющие системы и подсистемы должны описываться и рассматриваться в рамках единых принципов (как с точки зрения параметров моделей, так и с точки зрения критериев эффективности), не исключающих необходимость учета специфики каждой конкретной системы. Большинство реальных задач должно быть сведено к набору типовых задач моделирования.

Принциn оперативности. При управлении пограничной деятельностью в режиме реального времени данные и результаты расчетов, необходимые для принятия решений, должны поступать во время. Оперативность подготовки данных и выполнения расчетов достигается, в том числе и за счет автоматизации сбора данных и решения расчетных задач.

Принцип ингерентности. Система методов и моделей пограничной безопасности должна быть согласована с культурной средой, в которой ей предстоит функционировать. Она должна быть написана в терминах, которыми оперируют специалисты по пограничной безопасности. Исходя из данного принципа, можно сформулировать требования к моделированию. Требование наследования: разрабатываемые методы и модели должны включать и/или учитывать существующие методики расчетов как частный случай. Требование обучения: должна быть создана система обучения применению методов и моделей при решении пограничных задач.

Принцип nростоты. Простота методов и моделей с неизбежностью следует из-за необходимости оперирования ими, использования их в качестве рабочего инструмента, который должен быть доступен каждому, кто будет участвовать в реализации моделей. По Г. Саймону наблюдаемое разнообразие и сложность поведения людей объясняется не сложностью принципов принятия ими решений (выбора действий), а разнообразием ситуаций, в которых принимаются решения. Из принципа простоты вытекает требование по использованию на практике при прочих равных условиях наиболее простых схем, моделей, методик, программ.

Принцип адекватности. Система методов и моделей (ее структура, сложность, функции и т.д.) должна быть адекватна (соответственно, структуре, сложности, функциям и т.д.) задачам по обеспечению пограничной безопасности. Адекватность моделей означает, что они достаточно полны, точны и истинны. Достаточно не вообще, а именно в той мере, которая позволяет достичь поставленной цели. 


\section{2. Последовательность разработки методов и моделей пограничной безопасности}

Представляется целесообразной следующая последовательность деятельности по разработке и внедрению методов и моделей пограничной безопасности.

1-й эman. Уточнение и декомпозиция целей, мер и задач, решаемых обществом, государством, ведомствами, органами местного самоуправления в интересах укрепления пограничной безопасности.

2-й этan. Уточнение методов моделирования и типов моделей, используемых (рекомендуемых к использованию) в теории и практике пограничной деятельности России и других государств.

3-й этan. Инвентаризация моделей и математического обеспечения, используемых в практической, научной и образовательной деятельности.

4-й эman. Сопоставление списка задач по обеспечению пограничной безопасности и списка имеющихся моделей.

5-й эman. На основе сопоставления списков формулирование требований на разработку информационных, математических, имитационных и других моделей.

6-й этan. Разработка методов и моделей пограничной безопасности.

7-й этan. Разработка комплекса мер по приемке, внедрению методов и моделей пограничной безопасности в практическую деятельность, образовательный процесс, разработка специального математического и программного обеспечения.

Далее рассмотрим содержание работ 1-го и 2-го этапов, основанное на классификации комплекса пограничных мер и соответствующим им методам моделирования.

\section{3. Классификация моделей управления пограничной безопасностью}

Можно выделить три вида моделей управления пограничной безопасностью ${ }^{6}$ (первое основание классификации -уровень абстрактности/конкретности рассмотрения деятельности по обеспечению пограничной безопасности):

1. Концептуальные модели (погранология, пограничный менеджмент - Border Management):

- цели, задачи, нормы и принципы пограничной деятельности;

- $\quad$ функции границ, пограничных средств и пограничной политики;

- $\quad$ пограничные воздействия, циклы деятельности и др.

2. Описательные модели (модели оценки эффективности):

- аналитические (теория вероятностей, теория поиска и статистических решений, теория надежности, теория массового обслуживания, теория экспертных оценок);

- $\quad$ имитационные (дифференциальные уравнения, Марковские цепи и конечные автоматы, агентное моделирование). Модели управления и противоборства:

6 Новиков Д.А. Методология управления. М.: Книжный дом «ЛИБРОКОМ», 2012. 128 с. Новиков Д.А. Иерархические модели военных действий / Управление большими системами. Выпуск 37. М.: ИПУ РАН, 2012. С. 25-62. 


\section{3. Модели управления и противоборства:}

- аналитические (математическое программирование, оптимальное управление, дискретная оптимизация, календарно-сетевое планирование и управление, многокритериальное принятие решений, матричные, биматричные, дифференциальные и другие игры);

- имитационные игры и экспертизы;

- служебные, административные, военные и деловые игры.

Вторым основанием классификации моделей управления пограничной безопасностью является масштаб реальных систем, для использования в которых в основном предназначена та или иная модель (класс моделей): Союз (Содружество) государств - государство и общество - регион - район - участок (подразделение, группа) - индивидуум.

Управление пограничной безопасностью является одним из видов государственного управления, что обусловливает третье основание классификации моделей - по функциям государственного управления в сфере пограничной деятельности. Можно выделить следующие функции управления (и соответствующие им модели управления пограничной безопасностью)7: информационное обеспечение управления; прогнозирование и моделирование; планирование; организация; распорядительство; руководство; координация; контроль; регулирование; учет.

Четвертое основание классификации моделей управления пограничной безопасностью - по функциям исполнительной власти8: правоприменительная; правозащитная; социально-экономическая; обеспечения законности и порядка; регулирующая; нормотворческая; охранительная (юрисдикционная).

Примерно до 1980-х годов в оперативно-тактических расчетах использовались в основном методы теории вероятностей и теории поиска, что было обусловлено сложившейся на тот момент системой образования и подготовки пограничных кадров. В последующем стал применяться весь спектр моделей оценки эффективности, управления и противоборства. Обзор используемых в теории и практике пограничной деятельности математических моделей представлен в работах «Введение в погранометрику» и «Классификация и обзор погранометрических моделей»9.

Для реализации ряда функций пограничной политики (профилактической, информационного управления) важно иметь не только модели пограничного ведомства, но и межведомственные, социально-политические, экономические и иные модели, в которых исследуется деятельность общественных и иных организаций по обеспечению погранич-

7 Бахрах Д.Н. Административное право: Учебник / Д.Н. Бахрах, Б.В. Россинский, Ю.Н. Старилов. 3-е изд., пересмотр. и доп. М.: Норма, 2008. С. 39-43.

8 Там же. С. 53-54.

9 Беляков С. А., Борисов В. И., Шумов В. В. Введение в погранометрику. М.: Пограничная академия ФСБ России, 2012. 667 с.

Шумов В.В. Классификация и обзор погранометрических моделей / Труды ИСА РАН, 2012. Том 62.1. С. 26-39. 
ной безопасности («Границу Родины охраняет весь советский народ» ${ }^{10}$ ).

\section{4. Методы управления пограничной безопасностью}

Метод - это сознательный способ достижения какого-либо результата, осуществления определенной деятельности, решения некоторых задач. Метод предполагает известную последовательность действий на основе плана в самых различных видах познавательной и практической деятельности11. Метод может включать меры - «действия или совокупность действий и средств, направленных на осуществление или достижение чего-либо»12.

На рис. 1 показан метод управления пограничной безопасностью, основанный на комплексном и системном управлении мерами ${ }^{13}$.


Рис. 1. Метод управления пограничной безопасностью

В юридической литературе под правовым режимом понимается «официально установленный особый порядок правового регулирования, отражающий совокупность юридических и организационных средств, используемых для закрепления социально-правового состояния объектов воздействия и направленный на обеспечение их устойчивого функционирования» 14 .

10 Часовые советских границ: Краткий очерк истории пограничных войск СССР /

В.С. Иванов, Ю.Г. Кисловский, В.Н. Андриянов и др.. 2-е изд., доп. М.: Политиздат, 1983. C. 16.

11 Новая философская энциклопедия: в 4 т. / Ин-т философии Российской акад. наук;

Гл. ред. В. С. Степин. М.: Мысль, 2000-2001.

12 Ефремова Т. Ф. Новый словарь русского языка. Толково-словообразовательный. М.: Русский язык, 2000.

13 Постановление Межпарламентской Ассамблеи государств - участников Содружества Независимых Государств от 28 октября 2010 г. N 35-10 «О модельном законе «О пограничной безопасности».

Шумов В.В. Введение в методологию погранологии и погранометрики / Под ред. и с предисл. В.А. Дмитриева. М.: Книжный дом «ЛИБРОКОМ», 2013. 200 с.

14 Бахрах Д.Н. Административное право: Учебник / Д.Н. Бахрах, Б.В. Россинский, Ю.Н. Старилов. 3-е изд., пересмотр. и доп. М.: Норма, 2008. С. 478. 


\section{5. Управление режимными мерами}

Правовой режим состоит из следующих элементов (основание классификации - состав режима) ${ }^{15}$ :

- $\quad$ носитель режима - институты, организации, территории, процессы, предметы, деятельность, в интересах кого (чего) осуществляется правовое регулирование;

- $\quad$ режимные правовые средства - нормативные предписания, акты реализации прав и обязанностей субъектов, правоприменительные акты, меры поощрения и принуждения, юридические санкции, методы и приемы административной деятельности;

- $\quad$ режимные правила - особое сочетание правовых средств, создающих нормативную модель поведения и регламентирующих порядок пользования субъективными правами, полномочиями, обязанностями, ограничениями;

- субъекты (участники) правовых режимов - физические и юридические лица, связанные с носителем режима и обязанные соблюдать установленные правила (или обеспечивающие соблюдение правил);

- система организационно-юридических гарантий, отвечающая за устойчивость режимных правил, их фактическую выполнимость, устранение возможных нарушений.

Основание классификации видов режима - носители правовых режимов.

На рис. 2 показаны состав, виды и предмет моделирования режимных мер. Предметом моделирования режимных мер являются структурные элементы режима (по видам режима), взаимосвязи между ними, связи режимных мер с пограничными мерами в интересах повышения эффективности пограничной деятельности.

\begin{tabular}{|c|c|c|c|c|}
\hline $\begin{array}{c}\text { Состав } \Downarrow \text { и виды } \Rightarrow \\
\text { режима }\end{array}$ & $\begin{array}{c}\text { Погранич- } \\
\text { ный режим } \\
\text { и режим } \\
\text { в пунктах } \\
\text { пропуска }\end{array}$ & $\begin{array}{c}\text { Режим } \\
\text { государственной } \\
\text { границы }\end{array}$ & $\begin{array}{c}\text { Режим исклю- } \\
\text { чительной } \\
\text { экономической } \\
\text { зоны и др. }\end{array}$ & $\begin{array}{c}\text { Режим } \\
\text { пограничных и } \\
\text { др. операций, } \\
\text { чрезвычайного } \\
\text { положения }\end{array}$ \\
\hline $\begin{array}{c}\text { Система } \\
\text { организационно- } \\
\text { юридических } \\
\text { гарантий }\end{array}$ & \multicolumn{4}{|c|}{$\begin{array}{l}\text { 1) Административная подсистема, наделенная полномочиями по } \\
\text { обеспечению и поддержанию режима. } \\
\text { 2) Совокупность юридических санкций за нарушение требований } \\
\text { режима. } \\
\text { 3) Организационные мероприятия, связанные с установлением } \\
\text { режима. } \\
\text { 4) Информационно-технические и другие средства, системы } \\
\text { мониторинга, экспертизы }\end{array}$} \\
\hline Субъекты режима & \multicolumn{4}{|c|}{$\begin{array}{l}\text { Физические и юридические лица, связанные с носителем режима и } \\
\text { обязанные соблюдать установленные правила }\end{array}$} \\
\hline
\end{tabular}

15 Там же. С. 479-481. 


\begin{tabular}{|c|c|c|c|c|}
\hline $\begin{array}{c}\text { Режимные } \\
\text { средства и правила }\end{array}$ & \multicolumn{4}{|c|}{$\begin{array}{l}\text { Ограничительные и/или стимулирующие средства: меры поощрения и } \\
\text { принуждения, санкции, методы и приемы деятельности. } \\
\text { Правила - совокупность используемых правовых средств, } \\
\text { обеспеченные системой организационно-правовых мер }\end{array}$} \\
\hline Носитель режима & $\begin{array}{l}\text { Националь- } \\
\text { ная } \\
\text { территория } \\
\text { и объекты } \\
\text { на ней }\end{array}$ & $\begin{array}{c}\text { Национальные } \\
\text { территории } \\
\text { двух государств } \\
\text { вблизи границы }\end{array}$ & $\begin{array}{c}\text { Территории со } \\
\text { смешанным } \\
\text { правовым } \\
\text { режимом }\end{array}$ & $\begin{array}{c}\text { Социальные } \\
\text { и природно- } \\
\text { техногенные } \\
\text { процессы }\end{array}$ \\
\hline
\end{tabular}

Рис. 2. Состав, виды и предмет моделирования режимных мер

Исходя из предмета моделирования, можно выделить, в частности, следующие виды моделей управления границами и режимными мерами:

- модели динамики территорий ${ }^{16}$ - управление носителями и субъектами режима;

- $\quad$ модели институционального и мотивационного управления - управление режим-

ными средствами и правилами;

- модели управления системой гарантий соблюдения режима;

- $\quad$ комплексные модели управления режимными мерами (по видам режима).

Как показывает обзор моделей пограничной безопасности, в настоящее время имеется недостаточное количество моделей управления границами и режимными мерами. Их разработка представляется важной научной и практической задачей.

\section{6. Управление профилактическими мерами}

В криминологии под профилактикой понимается воздействие на причины преступности и условия, способствующие ей. Профилактика считается наиболее важным видом борьбы с преступностью ${ }^{17}$. Следуя А.И. Долговой ${ }^{18}$ термины «предупреждение преступности» и «профилактика преступности» будем понимать как синонимы.

Борьба с преступностью включает следующие этапы: профилактика преступности - предотвращение преступлений - пресечение преступлений - исправление преступников $^{19}$. Им соответствуют следующие этапы пограничных мер: пограничная профилактика - пограничное сдерживание - пресечение нарушений режима - устранение последствий.

Первое основание классификации профилактических мер - субъекты предупрежде-

16 Alesina A., Spolaore E. On the Number and Size of Nations // Quarterly Journal of Economics, 1997. Vol. 113, P. 1027-1056.

Alesina A., Spolaore E. War, Peace and the Size of Countries // Journal of Public Economics, 2005. No 89 (7), P. 1333-1354.

17 Антонян Ю.М. Криминология. Избранные лекции. М.: Логос, 2004.

18 Криминология: Учебник для вузов / Под общ. ред. д. ю. н., проф. А.И. Долговой. 3-е изд., перераб. и доп. М.: Норма, 2005. С. 435.

19 Антонян Ю.М. Криминология. Избранные лекции. М.: Логос, 2004. 
ния. По данному основанию можно выделить 20 :

- профилактические меры со стороны общества в лице его различных институтов;

- профилактические меры со стороны государственных органов;

- $\quad$ профилактические меры со стороны физических и юридических лиц.

Второе основание классификации - уровень профилактической деятельности. По уровню деятельности выделяются21:

- $\quad$ общая профилактика - система мер, направленных на все население или отдельные группы, выделяемые по общим экономическим, социальным или иным критериям (молодежь, мигранты, безработные и т.д.);

- специальная профилактика - система мер, направленных на отдельные социальные группы, сферы деятельности, процессы, объекты, характеризующиеся повышенной вероятностью совершения правонарушений;

- индивидуальная профилактика - система мер, направленных на тех лиц, от которых можно ожидать правонарушений, а также на окружающую их социальную среду.

Tретье основание классификации - меры профилактических воздействий. По мерам воздействий выделяются:

- меры стимулирования;

- м меры ограничения.

Четвертое основание классификации - сферы психики, на которые направлены профилактические меры:

- потребностно-мотивационная;

- интеллектуально-познавательная;

- эмоционально-волевая;

- коммуникативно-поведенческая.

Пятое основание классификации - по фазам пограничной профилактики:

- прогнозирование;

- $\quad$ преэмптивные меры;

- $\quad$ превентивные меры.

Энциклопедический словарь дает следующее определение22: «Прогноз (от греческого prognosis - предвидение, предсказание) - конкретное предсказание, суждение о состоянии какого-либо явления в будущем». Нормативный прогноз - это предсказания, «цель которых заключается в том, чтобы вызвать интерес и побудить к действию»23.

Преэмпция (от лат. ргае - до, перед и emptio - покупка) является этапом цикла: ориентировка - выбор - исполнение (Circumspection - preemption - control cycle), - процес-

20 Криминология: Учебник для вузов / Под общ. ред. д. ю. н., проф. А.И. Долговой. 3-е изд., перераб. и доп. М.: Норма, 2005. 912 с.

21 Там же.

22 Советский Энциклопедический словарь. М.: Советская энциклопедия, 1988. С. 1063.

23 Эйрес Р. Научно-техническое прогнозирование и долгосрочное планирование.

М.: Мир, 1971. С. 58. 
са, в котором человек рассматривает несколько конструктов прежде, чем решить, как интерпретировать непривычное или неясное событие24. Преэмптивные меры направлены на предотвращение еще не сформированной, потенциальной угрозы, в то время как превентивные меры (prevention - предотвращение, препятствование) нацелены на нейтрализацию сформированных и очевидных угроз.

На рис. 3 показаны фазы, уровни и предмет моделирования профилактических мер 25 .

\begin{tabular}{|c|c|c|c|}
\hline $\begin{array}{c}\text { Фазы } \Rightarrow \text { и } \Downarrow \text { уровни } \\
\text { профилактики }\end{array}$ & Прогнозирование & $\begin{array}{c}\text { Преэмптивные } \\
\text { меры }\end{array}$ & $\begin{array}{c}\text { Превентивные } \\
\text { меры }\end{array}$ \\
\hline $\begin{array}{c}\text { Общая } \\
\text { профилактика }\end{array}$ & $\begin{array}{c}\text { Долгосрочные } \\
\text { прогнозы }\end{array}$ & $\begin{array}{l}\text { Управление } \\
\text { ценностями } \\
\text { пограничной } \\
\text { безопасности }\end{array}$ & $\begin{array}{c}\text { Управление } \\
\text { пограничной } \\
\text { безопасностью } \\
\text { как } \\
\text { общественным } \\
\text { благом }\end{array}$ \\
\hline $\begin{array}{c}\text { Специальная } \\
\text { профилактика }\end{array}$ & $\begin{array}{c}\text { Среднесрочное } \\
\text { прогнозирование }\end{array}$ & $\begin{array}{c}\text { Управление } \\
\text { социальной } \\
\text { средой }\end{array}$ & $\begin{array}{c}\text { Предотвраще- } \\
\text { ние пограничных } \\
\text { конфликтов }\end{array}$ \\
\hline $\begin{array}{c}\text { Индивидуальная } \\
\text { профилактика }\end{array}$ & $\begin{array}{c}\text { Краткосрочное } \\
\text { прогнозирование }\end{array}$ & $\begin{array}{c}\text { Управление } \\
\text { социально- } \\
\text { экономичес- } \\
\text { кими и др. } \\
\text { мерами }\end{array}$ & $\begin{array}{c}\text { Профилактика } \\
\text { правонарушений }\end{array}$ \\
\hline
\end{tabular}

Рис. 3. Фазы, уровни и предмет моделирования профилактических мер

Первым основополагающим началом борьбы с преступностью является примат предупредительной деятельности над правоохранительной, а в предупредительной деятельности - примат мер по оказанию социальной помощи нуждающимся в ней над предусмотренными законом ограничениями, приоритет мер убеждения перед принуждением ${ }^{26}$.

Индивид постоянно находится под воздействием социальных институтов: семьи,

24 Хьелл Л., Зиглер Д. Теории личности. СПб.: Питер, 2006. 607 с.

25 Кочнев И.П., Шумов В.В. Концепция преэмптивной войны и пограничная безопасность государства // XII Всероссийское совещание по проблемам управления ВСПУ-2014. М.: ИПУ РАН, 16-19 июня 2014. С. 6213-6219.

Шумов В.В. Пограничная безопасность как ценность и общественное благо // XII Всероссийское совещание по проблемам управления ВСПУ-2014. М.: ИПУ РАН, 16-19 июня 2014. С. 6271-6281.

26 Криминология: Учебник для вузов / Под общ. ред. д. ю. н., проф. А.И. Долговой. 3-е изд., перераб. и доп. М.: Норма, 2005. С. 392. 
религии или идеологии, культуры и традиций, системы образования, политики и рынка27. Профилактические меры реализуются через социальные институты, и в этой связи следует рассматривать задачи социально-информационного влияния, управления и противоборства 28.

Комплексность социально-информационного управления предполагает выполнение следующих функций (функции журналистики по В.Т. Третьякову): информационная, коммуникативно-интеграционная, vox populi (гласа народа - декларация интересов общества перед властью), политическая, историографическая, развлекательная функции, функция социализации людей.

В настоящее время имеется незначительное количество работ, посвященных проблеме моделирования и управления пограничной профилактикой. В то же время существует ряд исследований, посвященным вопросам прогнозирования, информационного управления и др.

\section{7. Управление охранно-контрольными и оперативно-силовыми мерами}

На рис. 4 показан предмет моделирования пограничных (охранно-контрольных и силовых) мер. Основание классификации - уровни угроз пограничной безопасности и носители режима.

\begin{tabular}{|c|c|c|c|c|}
\hline $\begin{array}{l}\text { Носитель режима } \\
\Rightarrow \text { и уровни } \Downarrow\end{array}$ & $\begin{array}{l}\text { Меры в пунктах } \\
\text { пропуска }\end{array}$ & $\begin{array}{l}\text { Меры на } \\
\text { государственной } \\
\text { границе }\end{array}$ & $\begin{array}{l}\text { Меры в } \\
\text { исключительной } \\
\text { экономической } \\
\text { зоне }\end{array}$ & Обеспечение \\
\hline \multirow{2}{*}{$\begin{array}{l}\text { Стратегический } \\
\text { уровень }\end{array}$} & \multicolumn{3}{|c|}{$\begin{array}{l}\text { Проектирование рациональных комплектов пограничных } \\
\text { сил, средств и структур }\end{array}$} & \multirow{2}{*}{$\begin{array}{c}\text { Кадровое, } \\
\text { финансовое, } \\
\text { научное } \\
\text { обеспечение }\end{array}$} \\
\hline & \multicolumn{3}{|c|}{ Проектирование пограничных мер } & \\
\hline \multirow[t]{2}{*}{$\begin{array}{l}\text { Оперативный } \\
\text { уровень }\end{array}$} & \multicolumn{3}{|c|}{$\begin{array}{l}\text { Пограничные и специальные операции: Сбор } \\
\text { информации - Поиск - Режимные действия - } \\
\text { Нейтрализация - Ликвидация последствий. } \\
\text { Боевые действия }\end{array}$} & \multirow[t]{2}{*}{$\begin{array}{c}\text { Системы } \\
\text { боевого и др. } \\
\text { обеспечения }\end{array}$} \\
\hline & \multicolumn{3}{|c|}{$\begin{array}{l}\text { Борьба с угрозами высокого (экстремизм, сепаратизм) и } \\
\text { высшего (защита границы) уровней }\end{array}$} & \\
\hline \multirow{2}{*}{$\begin{array}{c}\text { Тактический } \\
\text { уровень }\end{array}$} & \multicolumn{3}{|c|}{$\begin{array}{l}\text { Тактический пограничный цикл: Поиск - Обнаружение } \\
\text { - Распознавание - Наведение - Преследование - } \\
\text { Задержание - Фиксация признаков }\end{array}$} & \multirow{2}{*}{$\begin{array}{c}\text { Системы } \\
\text { материально- } \\
\text { технического } \\
\text { и др. } \\
\text { обеспечения }\end{array}$} \\
\hline & \multicolumn{3}{|c|}{$\begin{array}{l}\text { Борьба с угрозами низшего (нарушители режимов) и } \\
\text { среднего (нелегальная миграция, контрабанда, терроризм } \\
\text { и др.) уровней }\end{array}$} & \\
\hline
\end{tabular}

27 Третьяков В.Т. Специфика телевидения как аудивизуального средства массовой информации // Журналист. Социальные коммуникации, 2014. № 2 (14). С. 79-97. 28 Губанов Д.А., Новиков Д.А., Чхартишвили А.Г. Социальные сети: модели информационного влияния, управления и противоборства / Под ред. чл.-корр. РАН Д.А. Новикова. М.: Изд-во физ.-мат. лит-ры, 2010. 228 с. 
Базы знаний, интеллектуальные системы, экспертные системы, системы поддержки принятия решений

\begin{tabular}{|c|c|c|c|c|}
\hline $\begin{array}{c}\text { Носитель режима } \\
\Rightarrow \text { и уровни } \Downarrow\end{array}$ & $\begin{array}{c}\text { Меры в пунктах } \\
\text { пропуска }\end{array}$ & $\begin{array}{c}\text { Меры на } \\
\text { государственной } \\
\text { границе }\end{array}$ & $\begin{array}{c}\text { Меры в } \\
\text { исключительной } \\
\text { экономической } \\
\text { зоне }\end{array}$ & Обеспечение \\
\hline $\begin{array}{c}\text { Операционный } \\
\text { уровень }\end{array}$ & $\begin{array}{c}\text { Информацион- } \\
\text { ные средства } \\
\text { и технические } \\
\text { средства } \\
\text { паспортного } \\
\text { контроля }\end{array}$ & $\begin{array}{c}\text { Средства: загра- } \\
\text { дительные, поиска, } \\
\text { обнаружения, наве- } \\
\text { дения и преследо- } \\
\text { вания, задержания, } \\
\text { тактического сдер- } \\
\text { живания, фиксации } \\
\text { признаков }\end{array}$ & $\begin{array}{c}\text { Средства } \\
\text { мониторинга, } \\
\text { поиска, } \\
\text { распознавания, } \\
\text { задержания }\end{array}$ & $\begin{array}{c}\text { Средства } \\
\text { по видам } \\
\text { обеспечения, } \\
\text { расчет } \\
\text { коэффициентов } \\
\text { готовности }\end{array}$ \\
\hline
\end{tabular}

Рис. 4. Предмет моделирования охранно-контрольныхи оперативно-силовых мер

Действия по защите экономических интересов государства в исключительной экономической зоне имеют особенности, обусловленные физической средой, видом правонарушителей (в основном - промысловые суда) и т.д. В частности, тактический цикл по охране морских биоресурсов состоит из следующих основных этапов: своевременное обнаружение правонарушителей - контроль перемещений судов - информационноаналитическая работа - выбор позиции корабля (судна для досмотра) - контрольнопроверочные мероприятия.

На рис. 5 показана классификация моделей управления охранно-контрольными и силовыми мерами.

\begin{tabular}{|c|c|c|c|}
\hline 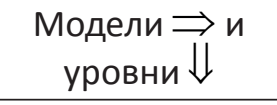 & $\begin{array}{c}\text { Концепции } \\
\text { (предмодели) }\end{array}$ & Описательные модели & $\begin{array}{c}\text { Модели управления и } \\
\text { противоборства }\end{array}$ \\
\hline $\begin{array}{c}\text { Стратегический } \\
\text { уровень }\end{array}$ & \multirow{4}{*}{$\begin{array}{l}\text { Концепции, } \\
\text { задачи, нормы, } \\
\text { принципы, } \\
\text { правила и } \\
\text { способы } \\
\text { действий }\end{array}$} & $\begin{array}{l}\text { Модели пограничных } \\
\text { структур, видов } \\
\text { обеспечения, систем } \\
\text { сотрудничества }\end{array}$ & $\begin{array}{l}\text { Оптимизация структур, } \\
\text { видов обеспечения, систем } \\
\text { сотрудничества. Перспек- } \\
\text { тивные возможности }\end{array}$ \\
\hline $\begin{array}{c}\text { Оперативный } \\
\text { уровень }\end{array}$ & & $\begin{array}{l}\text { Модели пограничных и } \\
\text { специальных операций, } \\
\text { боевых действий и их } \\
\text { эффективность }\end{array}$ & $\begin{array}{l}\text { Управление служебными } \\
\text { возможностями пограничных } \\
\text { сил и средств в операциях и } \\
\text { боевых действиях }\end{array}$ \\
\hline $\begin{array}{c}\text { Тактический } \\
\text { уровень }\end{array}$ & & $\begin{array}{l}\text { Модели подразделений, } \\
\text { мер, систем обеспечения } \\
\text { и их эффективность }\end{array}$ & $\begin{array}{l}\text { Управление служебными } \\
\text { возможностями пограничных } \\
\text { подразделений (с учетом } \\
\text { противодействия субъектов } \\
\text { воздействия) }\end{array}$ \\
\hline $\begin{array}{c}\text { Операционный } \\
\text { уровень }\end{array}$ & & $\begin{array}{l}\text { Модели пограничных } \\
\text { средств и их эффек- } \\
\text { тивность (служебный } \\
\text { потенциал) }\end{array}$ & $\begin{array}{l}\text { Управление служебными } \\
\text { возможностями погранич- } \\
\text { ных средств (с учетом } \\
\text { противодействия субъектов } \\
\text { воздействия) }\end{array}$ \\
\hline
\end{tabular}

Рис. 5. Модели управления охранно-контрольными и силовыми мерами 
Описательные модели предназначены для оценки эффективности пограничных средств (в том числе и со встроенными средствами автоматизации). Поиск оптимальных решений (с точки зрения субъекта управления) выполняется в задачах управления. Ситуации, когда на объекты управления (правонарушителей, сотрудников) оказывают воздействия несколько субъектов (руководители пограничных органов, трансграничные преступные группировки), рассматриваются в моделях противоборства.

Представленная классификация методов и моделей может лечь в основу научных и организационно-научных работ по систематизации моделей пограничной безопасности, выявлению перечня актуальных направлений исследований.

Отдельного рассмотрения заслуживают инфраструктурные модели (управление оборудованием границы, управление запасами и поставками и т.д.).

\section{3. Методология автоматизации пограничной деятельности}

Методология - это учение об организации деятельности 29 . Воспользуемся методологией еТОМ (инструментальным средством для моделирования, оптимизации и реорганизации производственных процессов и структуры организаций связи) ${ }^{30}$ для обоснования рационального подхода к автоматизации пограничной деятельности.

По методологии еТОМ стандартные группы процессов уровня 1 (верхнего уровня) и элементы процессов уровней 2 и 3 являются категориями, используемыми для классификации производственных процессов организации, а не моделями реальных процессов. Они определяются с максимально возможной степенью общности таким образом, чтобы быть независимыми от продуктов, услуг и технологий.

Построение эффективных (приспособленных к решению служебных задач) автоматизированных систем (AC) с точки зрения заказчика (руководителей пограничных органов) включает пять этапов (рис. 6). На первом этапе определяются границы решения исходя из документов, характеризующих цели решения, существующие в настоящей и будущей среде.

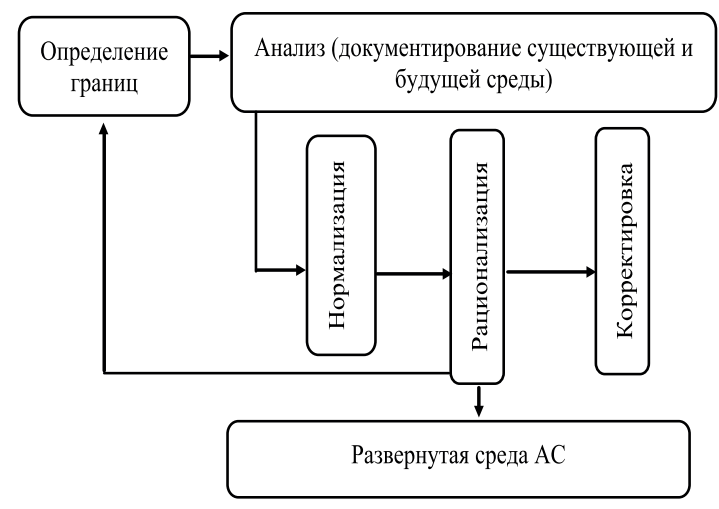

Рис. 6. Взаимосвязь этапов создания AC

29 Новиков А.М., Новиков Д.А. Методология. М.: СИНТЕГ. С. 20.

30 ГОСТ 53633.5-212. Расширенная схема деятельности организации связи (еТОМ). М.: Стандартинформ, 2013. 
На этапе анализа готовится подробная документация по существующим и будущим процессам охраны границы. Документируются процессы, информация, политики. Уточняются пропущенные или дублирующиеся функции. Процесс нормализации облегчает взаимодействие различных физических представлений, основанных на одном и том же логическом представлении.

На этапе рационализации определяются новые процессы, политики и технологии, которые должны быть разработаны.

На этапе корректировки вводятся новые процессы, политики и технологии, позволяющие заполнить пробелы, выявленные в ходе рационализации.

Пограничная деятельность протекает в форме процессов. На рис. 7 процессы управления пограничными мерами 1-го уровня классифицированы по функции управления 31.

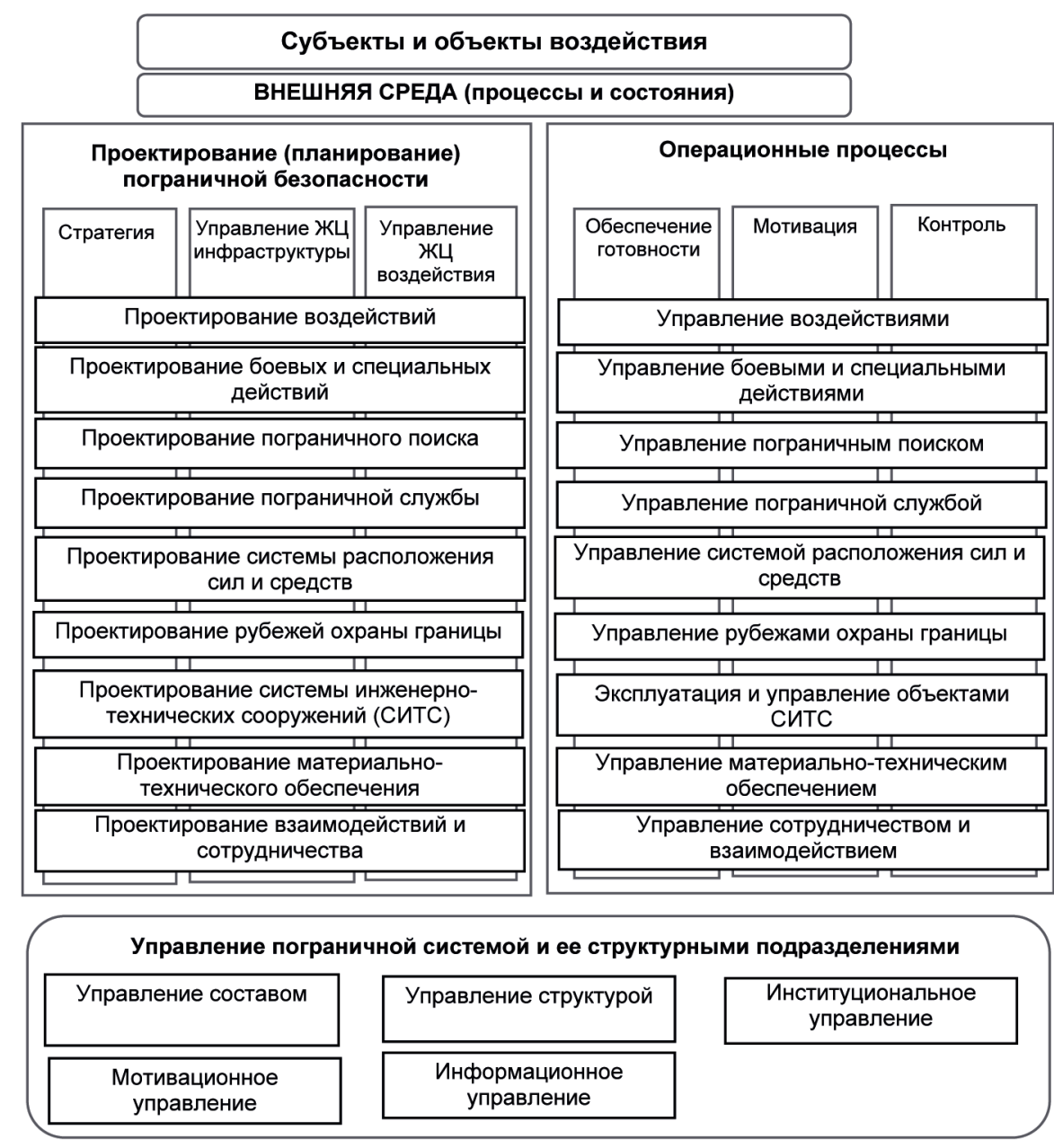

Рис. 7. Структурная схема процессов (вариант)

31 Различают процессное управление - управление регулярной, повторяющейся деятельностью, и управление проектами - управление изменениями (проектом называется ограниченное во времени целенаправленное изменение отдельной системы с установленными требованиями к качеству результатов, возможными рамками расхода средств и ресурсов и специфической организацией). 
Проектный блок включает три сквозных вертикальных группы процессов:

- стратегия (уяснение целей и задач охраны границы, принятие решения, формулирование требований и т. д.);

- $\quad$ управление жизненным циклом инфраструктуры (развертывание или создание в рамках принятого решения необходимой инфраструктуры: всестороннее обеспечение и управление, инженерное оборудование участка и т. д.);

- $\quad$ управление жизненным циклом воздействий (исходя из поставленных задач и на основе созданной инфраструктуры разработка новых тактических приемов и способов действий).

Процессный блок также включает три сквозных вертикальных группы процессов:

- обеспечение готовности - планирование, организация и поддержка на требуемом уровне регулярных, ежедневно исполняемых процессов;

- мотивация (стимулирование);

- контроль.

Выделение вертикальных групп процессов позволяет достичь решения следующих задач:

- обеспечить единство, согласованность и определенную последовательность действий всех подразделений и служб пограничного уровня;

- $\quad$ внедрить единый программный комплекс (автоматизированную систему) для поддержки сквозных процессов пограничного управления.

Основанием для последующей декомпозиции процессов пограничной службы могут быть:

- иерархический подход (каждому иерархическому уровню соответствует один и более уровней карты процессов);

- $\quad$ функциональный подход (процессы защиты и охраны границы; процессы защиты и охраны интересов государства в приграничной территории, в исключительной экономической зоне и на континентальном шельфе);

- с сочетание перечисленных подходов.

В качестве примера рассмотрим декомпозицию процесса нулевого уровня «Разработка и управление воздействиями» (рис. 8).

Последовательная декомпозиция процессов даст нам основное представление об их описании и содержании на всех уровнях иерархии пограничной службы. Чтобы обеспечить дальнейшее понимание того, как протекают эти процессы, можно выстроить их потоки 32 , что позволит определить, каким образом с помощью нескольких или всех процессов поддерживается некоторый более крупный, «сквозной» процесс в масштабах пограничной службы.

32 Поток (flow) - движение сил, средств, материалов и информации в процессе их преобразования в конечный продукт, услугу или воздействие. 


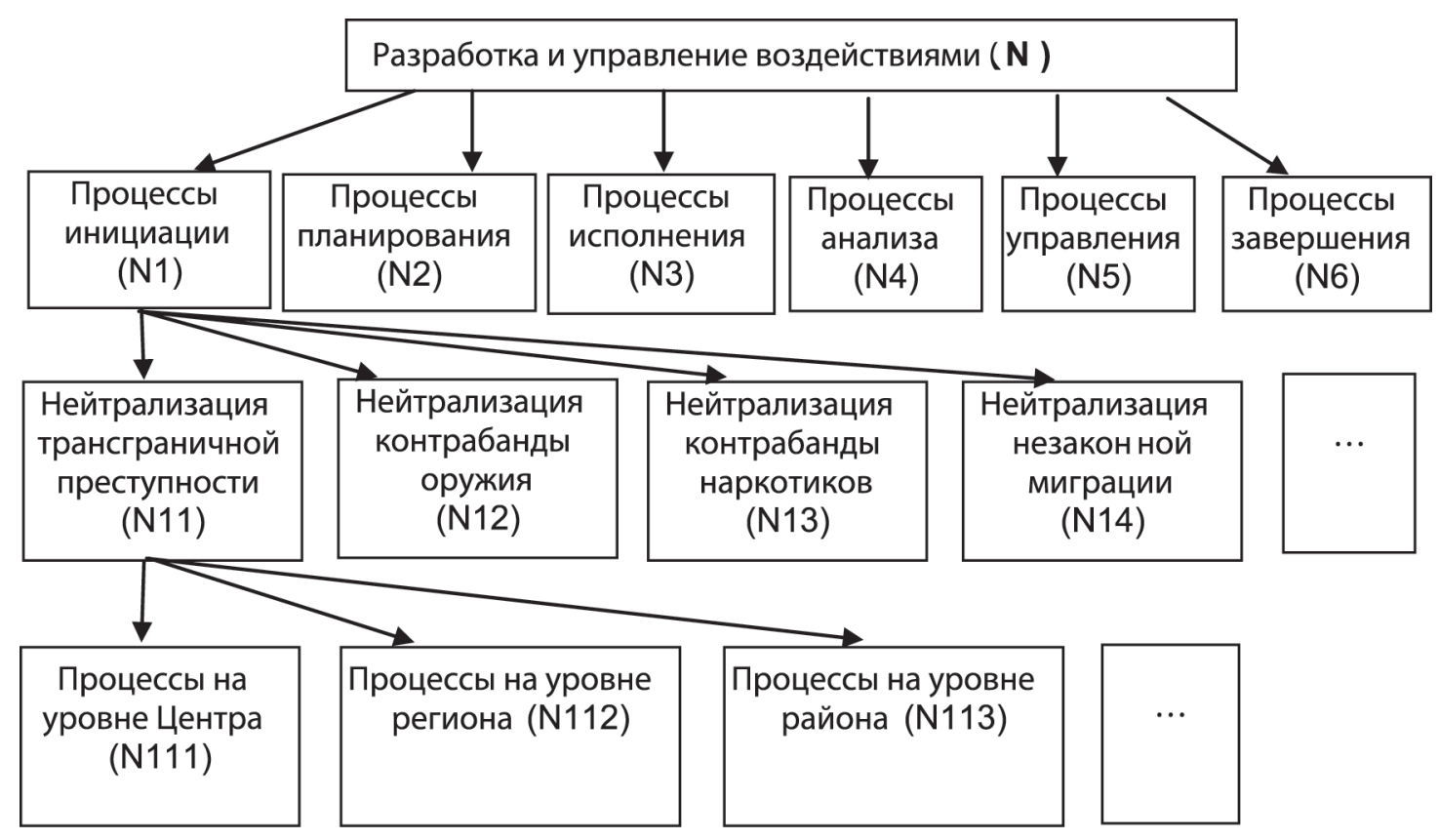

Рис. 8. Декомпозиция процесса (вариант)

Потоки процессов (рис. 9) позволяют изучить некоторый конкретный сценарий (ситуацию), с помощью которого эти процессы обеспечивают реализацию некоторой цели обеспечения пограничной безопасности.

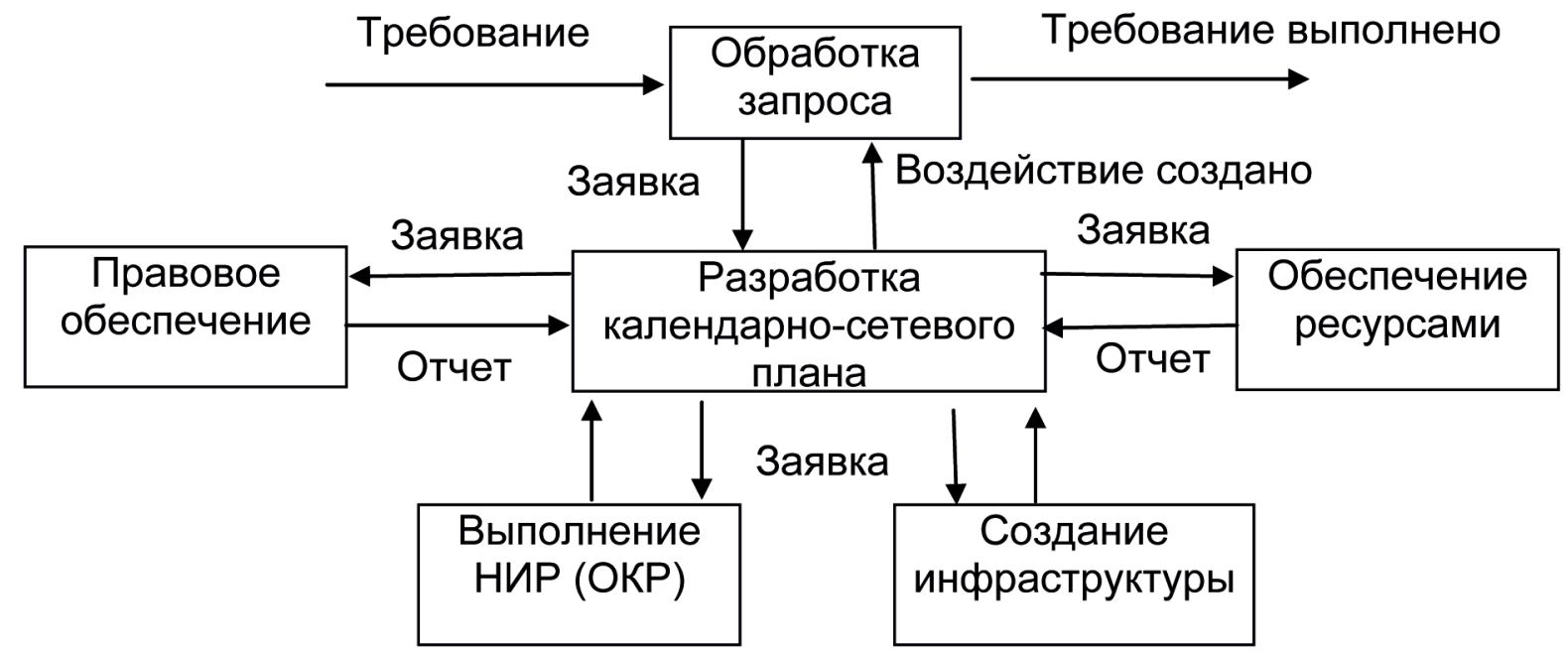

Рис. 9. Поток процессов (часть)

Метод построения последовательностей процессов имеет следующие общие характеристики:

- позволяет анализировать типичный (характерный) сценарий;

- дает представление о ходе и взаимодействии процессов; 
- позволяет выбрать уровень детализации, на котором будет выполняться моделирование последовательности;

- $\quad$ его цель - предоставить лишь пример последовательностей процессов, то есть в каждом сценарии описываются лишь некоторые из возможных взаимосвязей;

- обычно этот метод дает частичное представление о протекании процессов (поскольку последовательности строятся на основе характерных сценариев);

- обеспечивает динамическое представление процесса.

Построение последовательностей процессов завершается разработкой сетевых графиков для нескольких характерных сценариев.

Структура данных формируется в результате использования ER-моделей (модель «сущность-связь»)33. В основе структуры данных лежит понятие сущности. Под сущностью понимается объект, субъект, явление, имеющее интерес для пограничной службы. Сущности можно разделить на материальные (например, нарушитель границы), активные (нарушение границы) и концептуальные (угроза пограничной безопасности).У сущностей есть определенные признаки (атрибуты), так же сущности вступают в отношения с другими сущностями. Объектом называется совокупность свойств некоторой сущности и ее модели поведения. Декомпозиция процессов заканчивается формированием единой карты процессов и объектов (рис. 10).

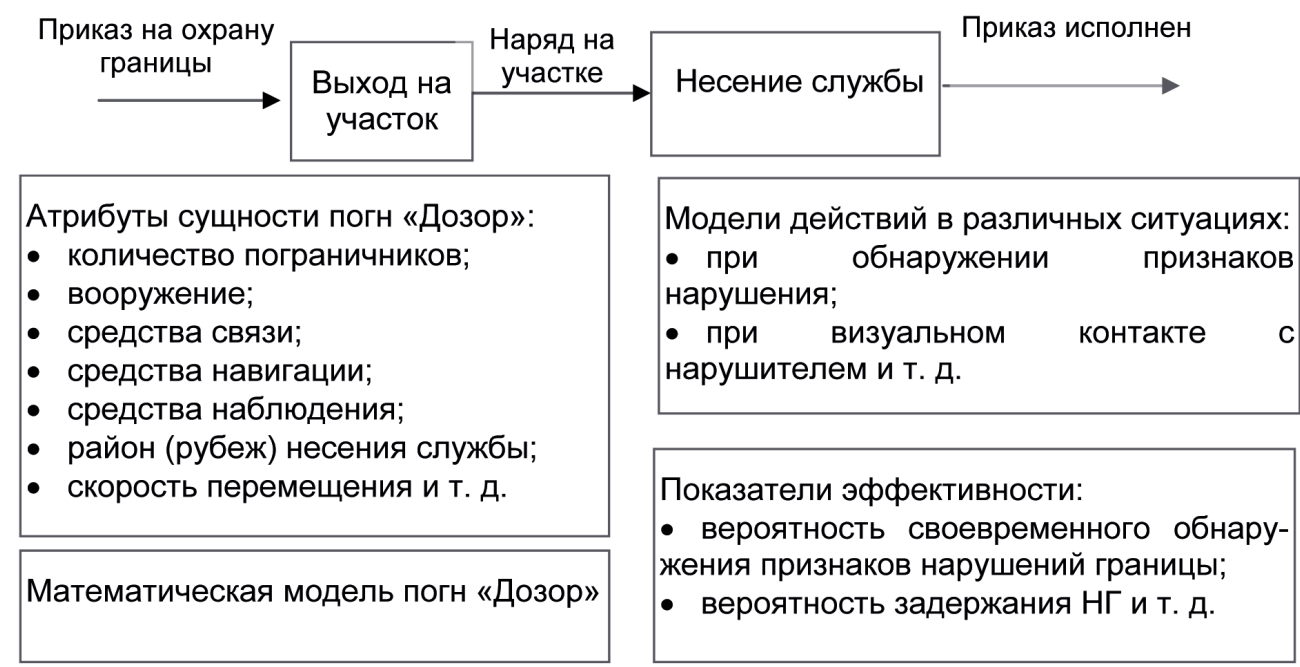

Рис. 10. Служба пограничного наряда (погн) «Дозор», процессы и информационная модель (вариант)

Отметим некоторые преимущества использования унифицированной модели данHbых 34 :

- $\quad$ модель не зависит от платформы (комплекс технических средств и операционная среда), языка программирования и протоколов взаимодействия;

- используются стандартные способы структурирования, определения и реализа-

33 Дейт К. Дж. Введение в системы баз данных. 8-е изд. М.: Вильямс, 2006. 1328 с.

34 Там же. 
ции информационных сущностей;

- единая, цельная и общая для всех подразделений и систем терминология.

Таким образом, нами получена рациональная последовательность построения комплекса автоматизированных систем в интересах обеспечения пограничной безопасности государства.

\section{4. Заключение}

В настоящей работе конкретизированы принципы моделирования пограничной деятельности, рассмотрена последовательность разработки методов и моделей пограничной безопасности, их классификация. Основной подход (совокупность приемов и способов) к разработке концепции автоматизации заключается в последовательной декомпозиции предметной области на основе классификации мер. Элементы предметной области объединяются в единую систему посредством выявления сквозных процессов, применения циклов пограничной деятельности и управления. Предложенные классификации методов управления режимными, профилактическими и пограничными мерами позволяют получить полный и непротиворечивый перечень пограничных задач, подлежащих автоматизации.

Также рассмотрена методология автоматизации пограничной деятельности, основанная на декомпозиции процессов пограничной безопасности.

Перспективным направлением исследований в области методологии автоматизации пограничной деятельности является дальнейшая декомпозиция процессов пограничной безопасности и построение списка потребных автоматизированных систем для каждого органа управления.

\section{Библиография :}

1. Антонян Ю.М. Криминология. Избранные лекции. М.: Логос, 2004.

2. Бахрах Д.Н. Административное право: Учебник / Д.Н. Бахрах, Б.В. Россинский, Ю.Н. Старилов. 3-е изд., пересмотр. и доп. М.: Норма, 2008. 816 с.

3. Беляков С. А., Борисов В. И., Шумов В. В. Введение в погранометрику. М.: Пограничная академия ФСБ России, 2012. $667 \mathrm{C}$.

4. Большая советская энциклопедия: В 30 т. М.: Советская энциклопедия, 1969-1978.

5. Википедия. ru.wikipedia.org.

6. ГОСТ 53633.5-212. Расширенная схема деятельности организации связи (еТОМ). М.: Стандартинформ, 2013.

7. Губанов Д.А., Новиков Д.А., Чхартишвили А.Г. Социальные сети: модели информационного влияния, управления и противоборства / Под ред. чл.-корр. РАН Д.А. Новикова. М.: Изд-во физ.-мат. лит-ры, 2010. 228 с.

8. Дейт К. Дж. Введение в системы баз данных. 8-е изд. М.: Вильямс, 2006. 1328 с.

9. Ефремова Т. Ф. Новый словарь русского языка. Толково-словообразовательный. М.: Русский язык, 2000. 
10. Кочнев И.П., Шумов В.В. Концепция преэмптивной войны и пограничная безопасность государства // ХІІ Всероссийское совещание по проблемам управления ВСПУ-2014. М.: ИПУ РАН, 16-19 июня 2014. С. 6213-6219.

11. Криминология: Учебник для вузов / Под общ. ред. д. ю. н., проф. А.И. Долговой. 3-е изд., перераб. и доп. М.: Норма, 2005. 912 c.

12. Новая философская энциклопедия: в 4 т. / Ин-т философии Российской акад. наук; Гл. ред. В. С. Степин. М.: Мысль, 2000-2001.

13. Новиков А.М., Новиков Д.А. Методология. М.: СИНТЕГ. 668 с.

14. Новиков Д.А. Методология управления. М.: Книжный дом «ЛИБРОКОМ», 2012. 128 с.

15. Новиков Д.А. Теория управления организационными системами. М.: МПСИ, 2005. 584 с.

16. Новиков Д.А. Иерархические модели военных действий / Управление большими системами. Выпуск 37. М.: ИПУ РАН, 2012. С. 25-62.

17. Постановление Межпарламентской Ассамблеи государств-участников Содружества Независимых Государств от 28 октября 2010 г. N 35-10 «0 модельном законе «0 пограничной безопасности».

18. Советский Энциклопедический словарь. М.: Советская энциклопедия, 1988. 1599 с.

19. Третьяков В.Т. Специфика телевидения как аудивизуального средства массовой информации // Журналист. Социальные коммуникации, 2014. № 2 (14). С. 79-97.

20. Х Хелл Л., Зиглер Д. Теории личности. СПб.: Питер, 2006. 607 с.

21. Часовые советских границ: Краткий очерк истории пограничных войск СССР / В.С. Иванов, Ю.Г. Кисловский, В.Н. Андриянов и др.. 2-е изд., доп. М.: Политиздат, 1983.318 с.

22. Шумов В.В. Введениев методологию погранологии и погранометрики / Подред. и спредисл. В.А.Дмитриева. М.: Книжный дОМ «ЛИБРОКОМ», 2013. 200 с.

23. Шумов В.В. Классификация и обзор погранометрических моделей / Труды ИСА РАН, 2012. Том 62.1. С. 26-39.

24. Шумов В.В. Пограничная безопасность как ценность и общественное благо // XII Всероссийское совещание по проблемам управления ВСПУ-2014. М.: ИПУ РАН, 16-19 июня 2014. С. 6271-6281.

25. Эйрес Р. Научно-техническое прогнозирование и долгосрочное планирование. М.: Мир, 1971. 295 с.

26. Alesina A., Spolaore E. On the Number and Size of Nations // Quarterly Journal of Economics, 1997. Vol. 113, P. 1027-1056.

27. Alesina A., Spolaore E. War, Peace and the Size of Countries // Journal of Public Economics, 2005. № 89 (7), P. 1333-1354.

\section{References:}

1. Antonyan Yu.M. Kriminologiya. Izbrannye lektsii. M.: Logos, 2004.

2. Bakhrakh D.N. Administrativnoe pravo: Uchebnik / D.N. Bakhrakh, B.V. Rossinskii, Yu.N. Starilov. 3-e izd., peresmotr. idop. M.: Norma, 2008.816s.

3. Belyakov S. A., Borisov V. I., Shumov V. V. Vvedenie v pogranometriku. M.: Pogranichnaya akademiya FSB Rossii, 2012. $667 \mathrm{~s}$.

4. Bol'shaya sovetskaya entsiklopediya:V 30 t. M.: Sovetskaya entsiklopediya, 1969-1978. 
5. Vikipediya. ru.wikipedia.org.

6. GOST 53633.5-212. Rasshirennaya skhema deyatel'nosti organizatsii svyazi (eTOM). M.: Standartinform, 2013.

7. Gubanov D.A., Novikov D.A., Chkhartishvili A.G. Sotsial'nye seti: modeli informatsionnogo vliyaniya, upravleniya i protivoborstva / Pod red. chl.-korr. RAN D.A. Novikova. M.: Izd-vo fiz.-mat. lit-ry, 2010. 228 s.

8. Deit K. Dzh. Vvedenie v sistemy baz dannykh. 8-e izd. M.:Vil'yams, 2006. 1328 s.

9. Efremova T. F. Novyi slovar' russkogo yazyka. Tolkovo-slovoobrazovatel'nyi. M.: Russkii yazyk, 2000.

10. Kochnev I.P., Shumov V.V. Kontseptsiya preemptivnoi voiny i pogranichnaya bezopasnost' gosudarstva // XII Vserossiiskoe soveshchanie po problemam upravleniya VSPU-2014. M.: IPU RAN, 16-19 iyunya 2014. S. 6213-6219.

11. Kriminologiya: Uchebnik dlya vuzov / Pod obshch. red. d. yu. n., prof. A.I. Dolgovoi. 3-e izd., pererab. i dop. M.: Norma, 2005. 912 s.

12. Novaya filosofskaya entsiklopediya: v 4 t. / In-t filosofii Rossiiskoi akad. nauk; GI. red. V. S. Stepin. M.: Mysl', 20002001.

13. Novikov A.M., Novikov D.A. Metodologiya. M.: SINTEG. 668 s.

14. Novikov D.A. Metodologiya upravleniya. M.: Knizhnyi dom «LIBROKOM», 2012. 128 s.

15. Novikov D.A. Teoriya upravleniya organizatsionnymi sistemami. M.: MPSI, 2005. $584 \mathrm{~s}$.

16. Novikov D.A. lerarkhicheskie modeli voennykh deistvii / Upravlenie bol'shimi sistemami. Vypusk 37. M.: IPU RAN, 2012. S. 25-62.

17. Postanovlenie Mezhparlamentskoi Assamblei gosudarstv-uchastnikov Sodruzhestva Nezavisimykh Gosudarstv ot 28 oktyabrya 2010 g. N 35-10 «0 model'nom zakone «0 pogranichnoi bezopasnosti».

18. Sovetskii Entsiklopedicheskii slovar'. M.: Sovetskaya entsiklopediya, 1988. $1599 \mathrm{~s}$.

19. Tret'yakov V.T. Spetsifika televideniya kak audivizual'nogo sredstva massovoi informatsii // Zhurnalist. Sotsial'nye kommunikatsii, 2014. № 2 (14). S. 79-97.

20. Kh'ell L., Zigler D. Teorii lichnosti. SPb.: Piter, 2006.607 s.

21. Chasovye sovetskikh granits: Kratkii ocherk istorii pogranichnykh voisk SSSR / V.S. Ivanov, Yu.G. Kislovskii, V.N. Andriyanov i dr.. 2-e izd., dop. M.: Politizdat, 1983. 318 s.

22. Shumov V.V. Vvedenie v metodologiyu pogranologii i pogranometriki / Pod red. i s predisl. V.A. Dmitrieva. M.: Knizhnyi dom «LIBROKOM», 2013.200 s.

23. Shumov V.V. Klassifikatsiya i obzor pogranometricheskikh modelei / Trudy ISA RAN, 2012. Tom 62.1. S. 26-39.

24. Shumov V.V. Pogranichnaya bezopasnost' kak tsennost' i obshchestvennoe blago // XII Vserossiiskoe soveshchanie po problemam upravleniya VSPU-2014. M.: IPU RAN, 16-19 iyunya 2014. S. 6271-6281.

25. Eires R. Nauchno-tekhnicheskoe prognozirovanie i dolgosrochnoe planirovanie. M.: Mir, 1971. $295 \mathrm{~s}$

26. Alesina A., Spolaore E. On the Number and Size of Nations // Quarterly Journal of Economics, 1997. Vol. 113, P. 1027-1056.

27. Alesina A., Spolaore E. War, Peace and the Size of Countries // Journal of Public Economics, 2005. No 89 (7), P. 13331354. 